\title{
LARAmie County Community College GEOLOGY OF YELLOWSTONE AND Grand Teton National Parks GEOL 1035-60 Summer 2012
}

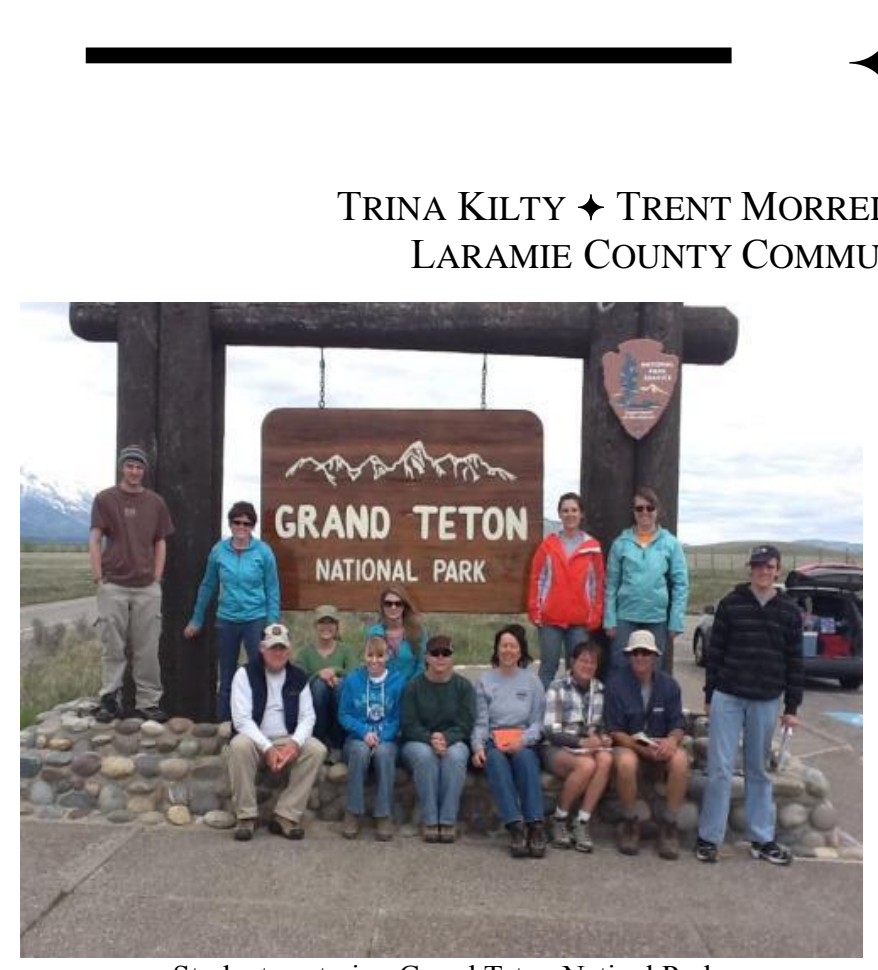

Students entering Grand Teton Natinal Park.

\section{$\downarrow$ Class OVERVIEW}

This is a 3 credit hour field course in geology offered through Laramie County Community College.

The title of the course is Geology of Yellowstone National Park (GEOL 1035-60).

\section{$\downarrow$ COURSE DESCRIPTION}

A study of Yellowstone's and the Grand Teton's earth materials and processes including rocks, minerals, streams, glacial history, geologic structures, earthquakes, and plate tectonics. Students acquire

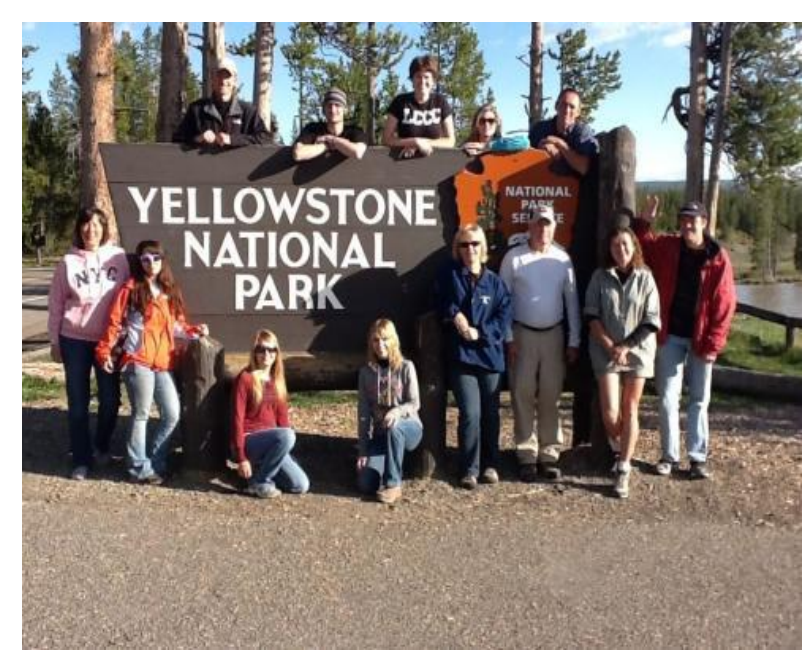

Students entering Yellowstone National Park.

scientific knowledge about the formation of Yellowstone's landscape, geothermal features, soils, and geologic hazards. Students will record observations and take notes in a field book that will be assessed as part of their grade.

\section{$\downarrow$ COURSE ObJECTIVE}

Students gain an understanding and appreciation of the geologic processes that form the Yellowstone and Teton landscapes. Participation in daily hikes, lectures, field note preparation and readings will allow students to comprehend the geology of the area. 
- We had 12 students participate in the course this year. The maximum enrollment is 13 .

- Students learn the basic geologic processes involved in the creation and continuous shaping of the Yellowstone and Grand Teton ecosystem. Participating students are to have had at least an introductory geology, physical geography or other Earth science class; or, have a specific interest in geosciences. Through the use of the text Windows into the Earth: The Geologic Story of Yellowstone and Grand Teton National Parks (Smith 2000); recording field notes and making sketches in their field books; and, by exploring and seeing geologic features and processes in the field during daily field trips, students get a front row seat to the show that is Earth in action (see attached course syllabus and schedule).

\section{$\downarrow$ COURSE BACKGROUND}

This is our fifth year to complete a successful geology field course in Yellowstone and the Grand Tetons; the first time coordinating and staying at the UW-NPS Research Station at the AMK Ranch. The course has typically run during our interim session between spring and summer semesters - generally in late may to early June.

\section{$\downarrow \quad$ Grand Teton National PaRk}

The field trips begin in Grand Teton National Park where students are introduced to the Teton and associated faults, glacial processes, and geologic hazards such as: earthquakes, landslides and floods. 